Review

\title{
Alternative Technologies for Biofuels Production in Kraft Pulp Mills-Potential and Prospects
}

\author{
Marcelo Hamaguchi $^{1, *}$, Marcelo Cardoso ${ }^{2}$ and Esa Vakkilainen ${ }^{1}$ \\ 1 Lappeenranta University of Technology_LUT Energy, Lappeenranta 20, FI-53581, Finland; \\ E-Mail: esa.vakkilainen@lut.fi \\ 2 Federal University of Minas Gerais (UFMG), Av. Antônio Carlos 6627, Pampulha, \\ Belo Horizonte-MG 31270-901, Brazil; E-Mail: marcelocardoso@globo.com \\ * Author to whom correspondence should be addressed; E-Mail: hamaguchi.marcelo@gmail.com; \\ Tel.: +358-46-643-7042; Fax: +358-5-621-6399.
}

Received: 22 May 2012; in revised form: 21 June 2012 / Accepted: 2 July 2012 /

Published: 6 July 2012

\begin{abstract}
The current global conditions provide the pulp mill new opportunities beyond the traditional production of cellulose. Due to stricter environmental regulations, volatility of oil price, energy policies and also the global competitiveness, the challenges for the pulp industry are many. They range from replacing fossil fuels with renewable energy sources to the export of biofuels, chemicals and biomaterials through the implementation of biorefineries. In spite of the enhanced maturity of various bio and thermo-chemical conversion processes, the economic viability becomes an impediment when considering the effective implementation on an industrial scale. In the case of kraft pulp mills, favorable conditions for biofuels production can be created due to the availability of wood residues and generation of black liquor. The objective of this article is to give an overview of the technologies related to the production of alternative biofuels in the kraft pulp mills and discuss their potential and prospects in the present and future scenario.
\end{abstract}

Keywords: biofuels; black liquor; kraft pulp mill; wood residues

\section{Introduction}

The need to turn away from the fossil fuel era has opened new opportunities for the use of products from renewable resources such as biomass. Being a non-fossil fuel, and a renewable organic material, 
biomass should be used to produce energy. The sources include terrestrial or aquatic vegetation, agricultural or forestry residues and industrial or municipal waste. It is believed that the use of biomass for energy and fuel production will be limited by maximum production rates and supply of biomass rather than the demand for energy and fuel [1]. In this scenario, the pulp mills have a large energy potential because they process a massive amount of lignocellulosic material, which represent the most significant percentage of vegetable biomass and the largest source of organic compounds in the biosphere. They contain varying amounts of cellulose, hemicellulose, lignin and a minor amount of extractives.

Cellulose is the main constituent of wood. It is a glucose polymer consisting of linear chains with an average molecular weight of approximately 100,000 grams per mole [2]. Since it is the main product of pulp mills, all the operating variables of the kraft process will be focused on obtaining maximum production of cellulose. Hemicellulose is a heterogeneous polymer composed of five-carbon and six-carbon monomeric sugars, with an average molecular weight of $<30,000$. Hardwoods are rich in five-carbon sugars while softwoods contain mostly six-carbon sugars. Hemicelluloses have the lowest average heating value among the components, Table 1. Removing the hemicelluloses from wood chips prior to pulping will provide kraft pulp mills with the opportunity to produce value-added products [3].

Lignin can be regarded as a group of amorphous, high molecular-weight, chemically related compounds. The building blocks of lignin are believed to be a three carbon chain attached to rings of six carbon atoms, called phenyl-propanes. Lignin has a higher heating value when compared to hemicellulose and is typically used as a fuel. Its structure suggests that it could also play an essential role as a chemical feedstock, particularly in the formation of supramolecular materials and aromatic chemicals [4].

Table 1 shows that there is variation in reported literature regarding the heating values of wood components [5-7]. They vary according to, for example, region and wood species. In most wood species, almost $40 \%$ to $45 \%$ of the dry substance is cellulose which is located primarily in the secondary cell wall. The amount of hemicelluloses and lignin in dry wood varies from $20 \%$ to $30 \%$ and from $20 \%$ to $40 \%$ respectively. However, there are variations in this percentage depending on the age, type and section of the wood. For example, there is approximately $28 \%$ lignin in stem wood, $36 \%$ in bark and $37 \%$ in branches, on a dry weight basis [8].

Table 1. Heating values of lignocellulosic components.

\begin{tabular}{lccc}
\hline & Minimum (MJ/kg) & Maximum (MJ/kg) & Average (MJ/kg) \\
\hline Cellulose & 16.1 & 19.0 & 17.6 \\
Hemicellulose & 14.7 & 18.2 & 16.5 \\
Lignin & 22.3 & 26.6 & 23.7 \\
Char & 25.4 & 37.2 & 31.3 \\
\hline
\end{tabular}

\section{Conventional Kraft Pulp Mills}

The primary goal of pulping is wood delignification. This process should be carried out while also preserving the cellulose and hemicelluloses to the possible extent and desirable amount. Such steps can be accomplished by using an aqueous solution containing hydroxyl $\left(\mathrm{OH}^{-}\right)$and hydrosulphide ( $\left.\mathrm{HS}^{-}\right)$ ions as active components. This solution, widely known as white liquor, is consumed during the cooking of wood chips in pressurized vessels at approximately $160-170{ }^{\circ} \mathrm{C}$ [9]. The result is the 
production of wood pulp containing dissolved organic and soluble inorganic materials. A washing stage is then needed to remove the majority of these materials. The washed pulp is sent to be screened and the separated liquid (black liquor), with a dry solids content of about $13 \%-16 \%$, is sent to the recovery line, Figure 1.

Figure 1. Overview of a kraft pulping process.

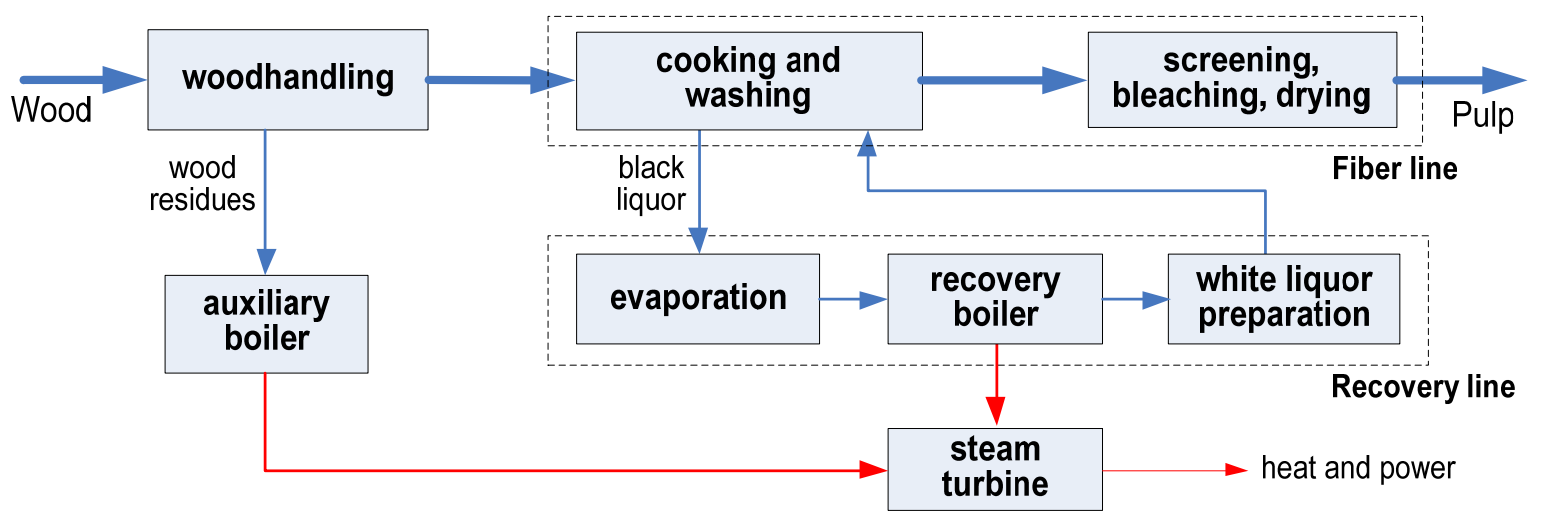

A chemical recovery cycle is necessary to make the pulping process economically feasible. After being concentrated to $65 \%-85 \%$ at the evaporation plant, it can be effectively burned in the recovery boiler for the regeneration of pulping chemicals. In turn, the boiler generates high pressure steam and reduces some waste streams in an environmentally friendly way. The non-combusted fraction becomes a hot molten inorganic flow, consisting mostly of sodium carbonate and sodium sulphide. This molten smelt is dissolved and subsequently pumped to the recausticizing plant for white liquor preparation.

Typically pulp mills also have to eliminate the wood residues generated in the wood handling area, which consist basically of barks, sawdust or fines from screening. They are normally burned in auxiliary boilers. The high pressure steam from both recovery and auxiliary boilers is sent to the turbo generators to produce power and heat for the mill.

\section{The Relevance of Wood Species for Biofuels Production}

The chemical composition and wood density of the species used, combined with the applied process conditions (e.g., target kappa numbers or if the pulp is bleached or unbleached), are important factors to be considered when studying the potential of biofuel production. They have a great influence on the specific consumptions of wood, chemical charge, black liquor characterization as well as effluent to treatment and emissions rate. One important difference that has a direct impact on the kraft pulping process can be found between softwoods (SW) and hardwood (HW), specifically with respect to the species composition, Table 2. 
Table 2. Examples of typical gross composition (\%) of wood species for pulping [10-12].

\begin{tabular}{|c|c|c|c|c|c|c|}
\hline Wood Species & Cellulose & Gluco-Mannan ${ }^{1}$ & Glucuronoxylan $^{2}$ & Lignin & Extractives & $\begin{array}{c}\text { Other Carbo- } \\
\text { Hydrates } \\
\end{array}$ \\
\hline \multicolumn{7}{|l|}{ Softwood } \\
\hline Pinus radiata (Monterey pine) & 37.4 & 20.4 & 8.5 & 27.2 & 1.8 & 4.3 \\
\hline Pinus sylvestris (Scots pine) & 40.0 & 16.0 & 8.9 & 27.7 & 3.5 & 3.6 \\
\hline Picea abies (Norway spruce) & 41.7 & 16.3 & 8.6 & 27.4 & 1.7 & 3.4 \\
\hline Picea glauca (White spruce) & 39.5 & 16.0 & 8.9 & 27.5 & 2.1 & 3.0 \\
\hline Larix sibirica (Siberian larch) & 41.4 & 14.1 & 6.8 & 26.8 & 1.8 & 8.7 \\
\hline \multicolumn{7}{|l|}{ Hardwood } \\
\hline Betula verrucosa (Silver birch) & 41.0 & 2.3 & 27.5 & 22.0 & 3.2 & 2.6 \\
\hline Betula papyrifera (Paper birch) & 39.4 & 1.4 & 29.7 & 21.4 & 2.6 & 3.4 \\
\hline Acer rubrum (Red maple) & 42.0 & 3.1 & 22.1 & 25.4 & 3.2 & 3.7 \\
\hline Eucalyptus globulus (Blue gum) & 51.3 & 1.4 & 19.9 & 21.9 & 1.3 & 3.9 \\
\hline Eucalyptus urophylla* & 51.0 & 1.5 & 14.9 & 26.1 & 2.5 & 4.0 \\
\hline Eucalyptus urograndis * & 49.5 & 1.4 & 15.0 & 27.8 & 2.0 & 4.3 \\
\hline Eucalyptus grandis $*$ & 48.7 & 1.5 & 16.2 & 26.1 & 1.8 & 5.7 \\
\hline Populous tremuloides (Aspen) ${ }^{3}$ & 44.5 & 1.7 & 21.4 & 23.3 & 2.1 & 7.0 \\
\hline
\end{tabular}

One example is the pulp yield (mass of brown stock pulp/mass of wood chips), which is strongly influenced by the wood species processed in the mill. One reason is that glucuronoxylan (main hemicellulose in HW) is more stable than glucomannan (main hemicellulose in SW) in the cooking process. In addition, the hardwood lignin shows a lower recondensation tendency than softwood lignins [9]. The result is a better selectivity and higher pulp yield for hardwoods.

Average yield values for bleached market pulp from softwood, birch and eucalyptus are in the range of $44 \%-48 \%, 49 \%-52 \%$ and $50 \%-54 \%$ respectively [13]. The higher yield for eucalyptus pulping can be expected given the high percentage of cellulose and differences in lignin reactivity. Santos et al. [14] reported higher delignification rates for hardwoods when compared to pine, with the highest value achieved with Eucalyptus globulus. Although a minor amount can be also dissolved during the kraft pulping, the cellulose is less susceptible to alkali or acid attack than hemicelluloses [9]. According to Grace and Malcolm [15], for a 50\% yield, about $20 \%$ of the original wood is lost due to polysaccharides, primarily hemicelluloses (amorphous structure). This leads to the fact that most of the hemicelluloses and almost all the lignin end up in the black liquor.

Another factor is related to the naturally occurring regional variability within species as well as the age of trees, which can lead to variations on pulp yield between mills using essentially the same raw material. In order to exemplify some of these effects, Table 3 attempts to illustrate some key factors related to the potential of alternative fuels in the pulp mills. The calculations are performed using a mill balance spreadsheet [16]. It can be observed that a higher pulp yield results in a lower load of organic material to the recovery process and a higher wood consumption per ton of pulp produced. The wood composition will also influence the process of hemicellulose extraction as well the production of tall oil from fatty acids and resins. 
Table 3. Examples of specific load variations in bleached pulp mills.

\begin{tabular}{lccccc}
\hline & & Scots Pine & Silver Birch & Eucalyptus Grandis & Eucalyptus Globulus \\
\hline Average Process Data & & & & & \\
\hline Pulp yield & $\%$ & 46.0 & 50.0 & 52.0 & 53.0 \\
Sulfidity & $\%$ & 40 & 35 & 32 & 28 \\
EA charge on dry wood & $\% \mathrm{NaOH}$ & 19 & 17 & 17 & 18 \\
\hline Calculated Values & & & & 1833 & 1815 \\
\hline Chips consumption & $\mathrm{kg}(\mathrm{dry}) / \mathrm{ADt}$ & 2090 & 1925 & 261 & 259 \\
Wood waste & $\mathrm{kg}(\mathrm{dry}) / \mathrm{ADt}$ & 298 & 274 & 452 & 375 \\
Lignin in black liquor & $\mathrm{kg} / \mathrm{ADt}$ & 540 & 399 & 1328 & 1320 \\
Black liquor yield & $\mathrm{kgDS} / \mathrm{ADt}$ & 1740 & 1450 & & \\
\hline
\end{tabular}

${ }^{1}$ Based on $1.5 \%$ screening loss, $10 \mathrm{wt} \%$ bark at delivery and $3 \%$ losses at debarking.

\section{Production of Alternative Biofuels in the Pulp Mills}

Figure 2 shows an overview of a pulp mill in which alternative technologies have been integrated for biofuel production. A kraft pulp mill with these technologies can present a number of opportunities to make bio-products at several points in the process. They are classified in this article as wood based and black liquor based technologies. Although it is possible to generate bioenergy through processes targeting the pulp mill waste streams e.g., biogas by anaerobic digestion of sludge [17], these processes will not be explored in this article.

Figure 2. The kraft pulp mill and the alternative technologies for biofuels production.

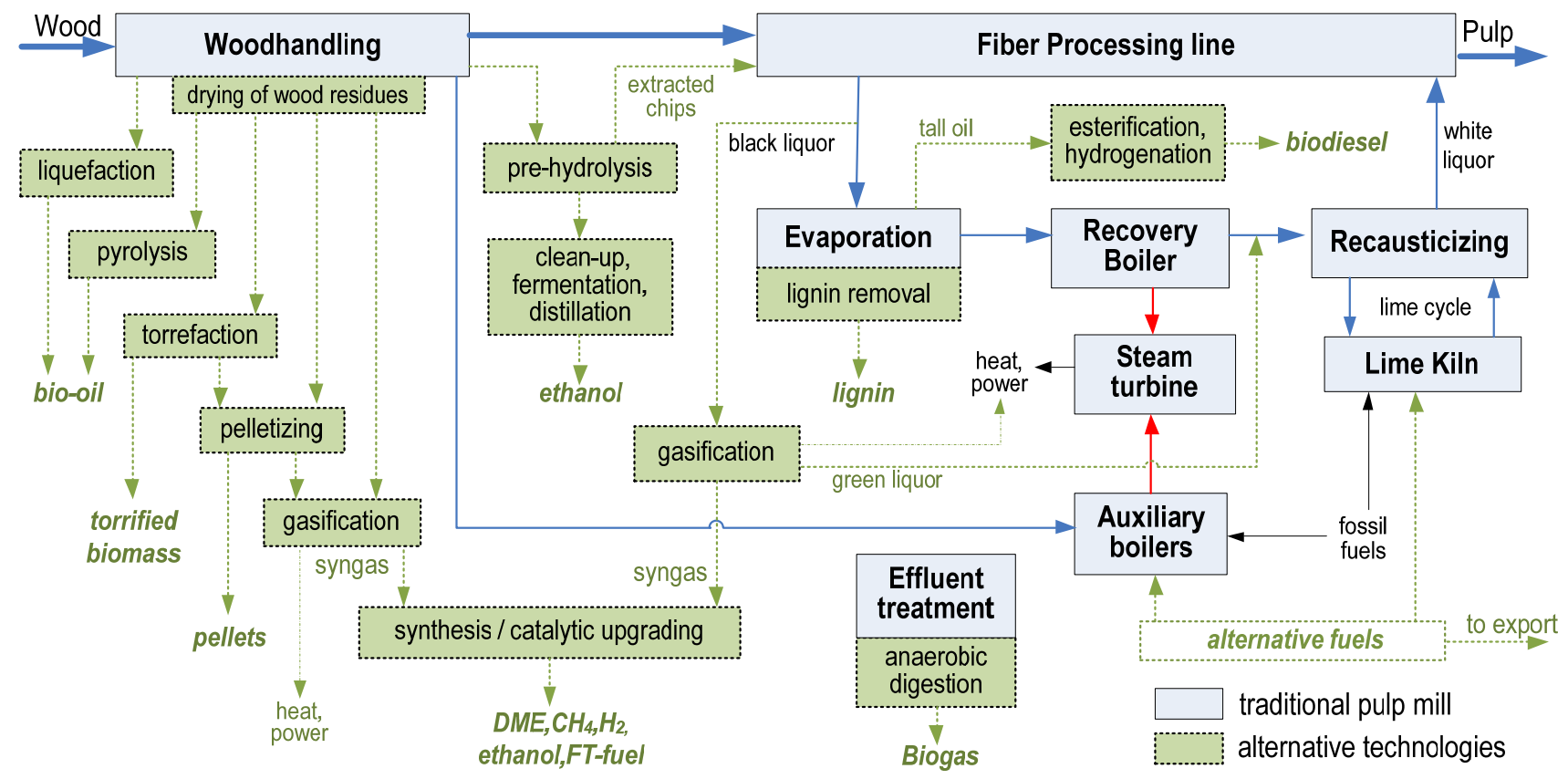

\subsection{Wood-Based Technologies}

Wood residues are considered attractive for being cheap and suitable as feedstock. Direct combustion is the traditional way of processing them in pulp mills. Alternative processes can be 
divided into physical, thermo-chemical and biochemical processes, Figure 3. If economically feasible, not only can generated wood waste be used as raw material but additional wood and bark brought from the forest can also be processed. One drawback is the high water content of biomass, which can range from $35 \%$ to $60 \%$ [18]. The value depends on the weather conditions and storage period after cutting the tree. For the optimum use in the pelletizing, torrefaction, gasification or pyrolysis processes, the moisture content has to be reduced to $10 \%-15 \%$, which is typically not required with direct combustion in efficient boilers. A drying pre-stage is then needed to fulfill the requirements. For such achievement, drying technologies using waste heat are available as reported by Johansson et al. [19]. Some dryers allow the use of, for example, hot water at $65-90{ }^{\circ} \mathrm{C}$ as a heat source.

Figure 3. Alternative technologies for biomass conversion to biofuels.

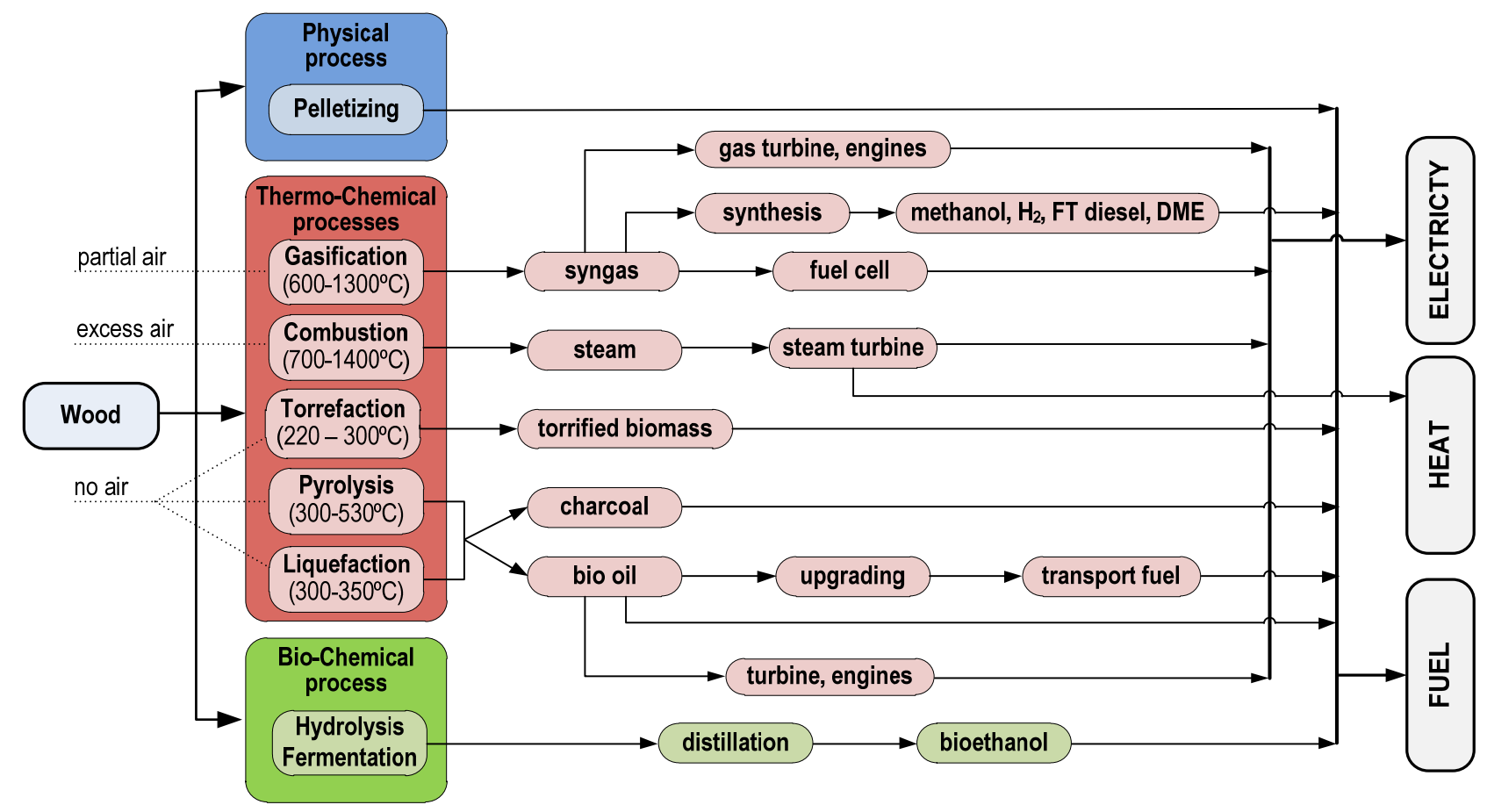

\subsubsection{Pelletizing of Wood Residues}

The pelletizing process is not necessarily only a physical process. There is usually the drying stage of biomass, which is a separate process that involves heat and mass transfer. However, almost no conversion of biomass occurs either by thermo-chemical or biochemical processes. In this article, the classification of a physical process is considered as being the occurrence of a significant change in biomass bulk density [20]. The bulk density of sawdust, for example, can be increased from $150 \mathrm{~kg} / \mathrm{m}^{3}$ to $600 \mathrm{~kg} / \mathrm{m}^{3}$ by pelletizing [18]. Advantages of this include improved handling, reduced transport costs and ability for stable storing. The pellets can be used as an environmentally friendly substitute to fossil fuels such as coal and petroleum products. End users also include the residential market and commercial power generation facilities, especially in central Europe.

Most pellets sold today are produced from sawmill by-products. They can also be produced from torrefied biomass, bark and residues streams such as tree tops and branches. A large part of the production cost of pellets is connected to the drying process. Anderson et al. [21] presented and 
evaluated different energy efficient options for integrating drying and pelletizing with a modern energy efficient pulp mill process. The results of the study indicated that the most attractive integrated drying technology option is the flue gas dryer, using flue gases from the black liquor recovery boiler. Because modern recovery boilers typically operate with high efficiency using the flue gas to produce hot pressurized water, the modern biomass dryers can use low pressure steam or other sources of waste heat.

\subsubsection{Torrefaction}

The objective of torrefaction is to create a solid biofuel with high energy density. The process occurs between 220 and $300{ }^{\circ} \mathrm{C}$ in the absence of oxygen, although some authors recommend not exceeding the limit of $280{ }^{\circ} \mathrm{C}$ to retain reasonable energy efficiency [22]. Under these conditions the moisture is removed and hemicellulose degraded, causing the release of acetic acid, fractions of phenol and other compounds of low heating value [23]. Lignin also suffers a slight polymerization. The resulting material is more brittle and has intermediate characteristics between coal and biomass.

The process causes a reduction in the energy content of the biomass because of partial devolatilization, but given the much higher reduction in mass, the energy density of the biomass increases. The average is a loss of $10 \%$ to $17 \%$ energy for $30 \%$ to $38 \%$ of original mass. A good review on biomass upgrading by torrefaction was recently published by van der Stelt et al. [24]. They emphasize that different reaction conditions (temperature, inert gas, reaction time) and wood type lead to different solid, liquid and gaseous products. As temperature and time increase, for example, the solid yield decreases and heating value $(\mathrm{kJ} / \mathrm{kg})$ increases.Another feature of torrefaction is that it reduces the hydroscopic property of biomass. As a consequence, torrefied product absorbs less moisture when stored. The fuel quality makes torrefied biomass very attractive for combustion and gasification applications in general [25,26]. Prins et al. [25] show that the thermodynamic losses are reduced if the biomass is torrefied prior to gasification.

There are different types of reactors that could be applied for the torrefaction process: rotary drum, screw conveyor, compact moving bed, microwave or belt conveyor. Although the heat integration for torrefaction can be designed in different ways, the developers typically apply the same basic concept in which the torrefaction gases are combusted in an afterburner [27]. The flue gas then provides, directly or indirectly, the heat necessary for the drying and torrefaction processes.

According to Table 3, one eucalyptus pulp mill producing 1.5M Adt/a of bleached pulp, for example, could generate approximately 390,000 t/a of dry wood waste that could be possibly torrefied. The biomass could be then converted to pellets for export. Determining the appropriate design for the heat integration in the mill is very important. Figure 4 suggests the direct heating of the biomass by using reheated volatiles gases. One disadvantage is that the concentration of organic acids and cyclic organic components will increase during the torrefaction process [27]. In addition, the energy content of the gases has to be sufficient to thermally balance the torrefaction process. Two options could be the use of flue gas from lime kiln or medium pressure steam. The optimized product and process can also depend on the customer requirements. 
Figure 4. Optional process for integrated torrefaction in a pulp mill.

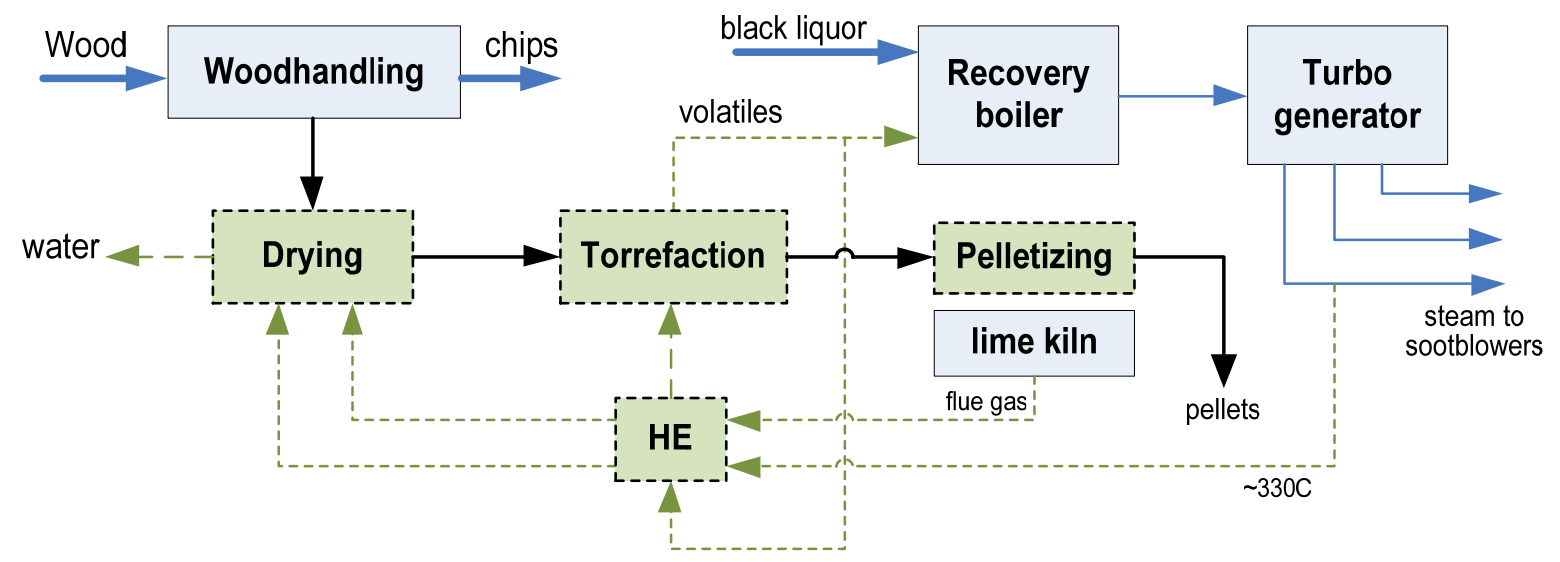

\subsubsection{Pyrolysis}

Pyrolysis is a thermal decomposition that takes place in the absence of oxygen, except in the case where partial combustion is allowed to provide thermal energy needed for this process. Large hydrocarbon molecules of biomass are broken down into smaller molecules. The pyrolysis can be broadly classified into slow and fast depending on the heating rate [28]. By also varying the residence time in the reaction zone and the final temperature, it is possible to change the relative yields of the solid, liquid and gaseous products of pyrolysis, Table 4.

Table 4. Examples of variation in the product yield of pyrolysis [29].

\begin{tabular}{cccc}
\hline Process & Temperature $\left({ }^{\circ} \mathbf{C}\right)$ & Residence Time & Product Yield (wt \%, solid, liquid, gas) \\
\hline \multirow{2}{*}{ Slow pyrolysis } & 316 & $200 \mathrm{~s}$ & $32-38,28-32,25-29$ \\
& 510 & $30 \mathrm{~s}$ & $22-28,23-29,40-48$ \\
Fast pyrolysis & 343 & $5 \mathrm{~s}$ & $29-34,46-53,11-15$ \\
Mild pyrolysis (Torrefaction) & 510 & $1 \mathrm{~s}$ & $9-13,64-71,17-24$ \\
Carbonation & 243 & $1800 \mathrm{~s}$ & $85-91,7-12,2-5$ \\
Gasification & 357 & days & mostly charcoal \\
\hline
\end{tabular}

The liquid fraction is known as bio-oil or pyrolysis oil. Maximizing its production is an attractive way of converting biomass into liquid, which can be done through fast pyrolysis, Table 4 . The heating value of crude bio-oil is in the range of 16 and $19 \mathrm{MJ} / \mathrm{kg}$ [30] and the operation at atmospheric pressure can lead to bio-oil yields higher than $70 \mathrm{wt} \%$. It is important to point out however that a reasonable fraction (15-30 wt \%) of the crude bio-oil consists of water from both the original moisture and reaction product. In addition, the biomass composition has a great influence on the preferred feedstock, since each lignocellulosic component decomposes with different kinetics. Moreover, pyrolysis reactions are catalyzed by alkali metal salts present in the biomass, which can result in a decrease in the bio-oil yield. Currently there are several types of pyrolysis reactors that could be used: bubbling or circulating fluidized bed, fixing or moving bed, ultra-rapid, rotating cone or ablative. Each of these categories includes different proprietary technologies. According to Basu [28], in most cases it is necessary to burn the solid and gas fractions generated during the pyrolysis to provide the heat 
required for the process. One example is the integrated combustion and pyrolysis process [31], where the unit utilizes the hot sand of the fluidized bed boiler as a heat source, Figure 5. The technology can be possibly implemented in existing pulp mills that already incinerate the wood residues in fluidized bed boilers.

Figure 5. Example of integrated combustion and pyrolysis.

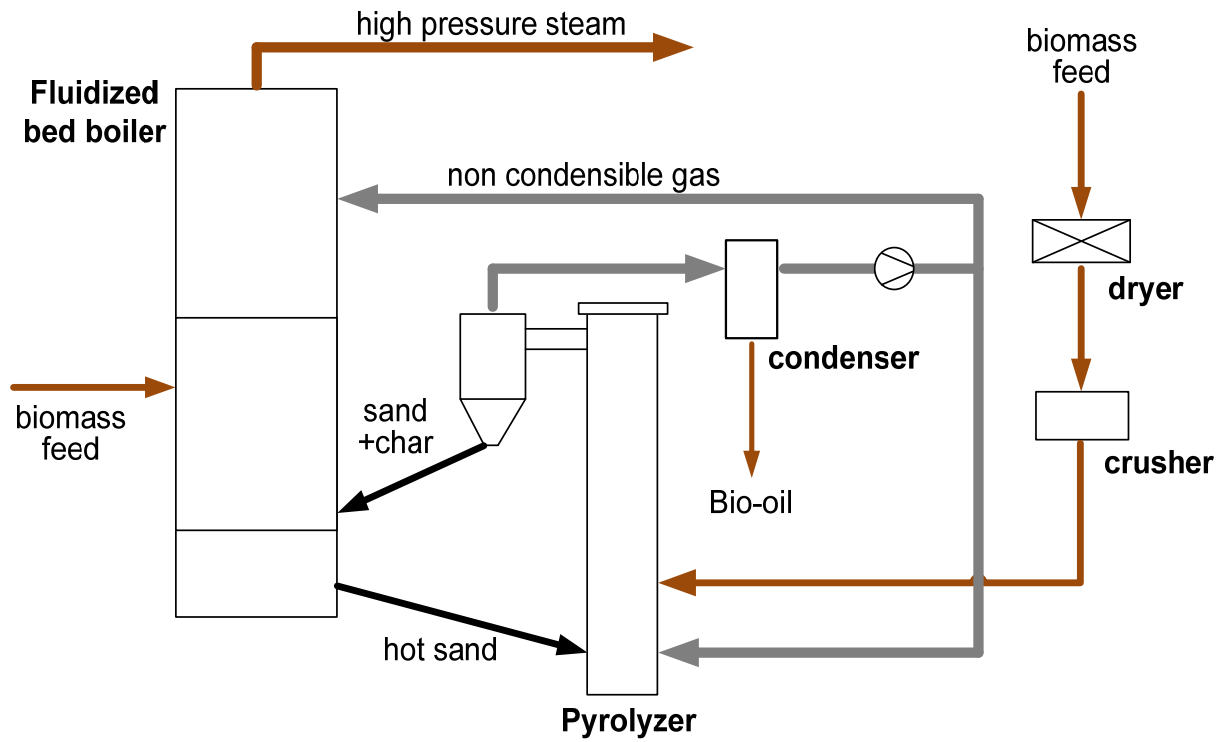

Another example of commercial technology for fast pyrolysis is the Rapid Thermal Processing $\left(\mathrm{RTP}^{\mathrm{TM}}\right)$ by Evergent [32]. It is a fast thermal process in which biomass is rapidly heated to approximately $500{ }^{\circ} \mathrm{C}$ in the absence of oxygen. A circulating transported fluidized bed reactor system is at the heart of the process. Contact with hot sand vaporizes the biomass, which is then rapidly quenched, typically yielding $55 \mathrm{wt} \%$ to $80 \mathrm{wt} \%$ of bio-oil depending on the process conditions and wood species, Table 5.

Table 5. Examples of bio-oil yields [33].

\begin{tabular}{ccc}
\hline Species & Bio-oil yield \% & Gross calorific value $\mathbf{M J} / \mathbf{k g}$ \\
\hline Hardwood & $70-75$ & $17.2-19.1$ \\
Softwood & $70-80$ & $17.0-18.6$ \\
Hardwood bark & $60-65$ & $16.7-20.2$ \\
Softwood bark & $55-65$ & $16.7-19.8$ \\
\hline
\end{tabular}

The phase-separation and polymerization of the liquids, as well as the corrosion trends in containers make storage of these liquids challenging [34]. Aging, which leads to an increase in viscosity with time, can be reduced or controlled by the addition of alcohols such as ethanol or methanol [35]. The bio-oil can be used for electricity generation in stationary diesel engines, boilers or turbines [30]. One alternative for pulp mills is to consume the oil produced in the lime kilns to reduce the fossil fuel consumption. For this purpose, some improvements are still required. Due to the higher density and lower heating value of bio-oil compared to light fuel oil, the fuel feeding system should be re-designed. The adaptation of equipment material is also important to avoid high levels of erosion/corrosion, which 
can be attributed to the bio-oil acidity and the presence of alkali and ash. Treatment includes filtration of bio-oil and upgrading through emulsification [36].

Another interesting and promising option is the upgrading of bio-oil to conventional transport fuel such as diesel, gasoline, kerosene, methane, jet fuels or LPG. This however requires full deoxygenation that can be accomplished, for example, by hydrotreating or integrated catalytic pyrolysis, followed by conventional refining. One implication of hydro-treatment is that the process requires high-pressure hydrogen, which is still not economically attractive. Regarding the integration of catalysis and pyrolysis, Bridgwater [35] suggests that sophisticated catalytic systems are needed, since the process requires operation at a single temperature and sufficiently robust catalyst to withstand the temperature and mechanical environment. The upgrading of bio-oil therefore has been constantly improved to become more competitive.

\subsubsection{Biomass Gasification}

The gasification involves conversion of carbonaceous materials, such as biomass, into useful gases and chemicals. It requires a medium for reaction and an operation temperature of 600 to $1300{ }^{\circ} \mathrm{C}$. The resulting gas mixture is called syngas (synthetic gas). The gasification medium can be supercritical water or gaseous (air, steam, $\mathrm{O}_{2}$ ) and has a great influence on the syngas composition and heating value. The advantage of gasification is that the burning of the syngas is more efficient than the direct combustion of the fuel. It also gives more flexibility to the process. It can be burned directly in gas engines or used to produce, for example, hydrogen or DME [37,38]. Via the Fisher-Tropsch process, the syngas can be converted into fuel such as diesel and gasoline. Based on the gas-solid contacting mode, gasifiers are classified into three principal types: fixed or moving bed; fluidized bed and entrained flow. Each is further subdivided into specific types.

A gasification system consists of four main stages: feeding, gasifier reactor, gas cleaning, and utilization of combustible gas. These stages are in continuous development and differ according to their application. The cleaning is the most crucial challenge in the development of advanced gasification based processes. There are always high amounts of impurities in the syngas such as particulates, heavy metals, tars and nitrogen compounds. The tar is an unavoidable by-product that condenses in the low temperature zones of the pyrolysis or gasification reactors. Two consequences include plugging of equipment downstream and formation of tar aerosols [27]. The situation has improved but tar removal remains an important part of the development of biomass gasifiers.

There are three main types of commercially used biomass gasifiers [28]: fixed bed (especially for small scales); bubbling fluidized bed (BFB) and circulating fluidized bed (CFB). The latter is suitable for biomass gasification in scale over $60 \mathrm{MW}$ [39]. Typically it comprises of a riser, a cyclone, and a solid recycle device. When entering the riser, which serves as a reactor, the biofuel particles start to dry in the hot gas flows at temperatures of $850-950{ }^{\circ} \mathrm{C}$. The release of combustible gas occurs after the remaining particles, which contain fixed carbon, are slowly gasified. The syngas contains all the formed volatiles. The gas passes by the cyclone to separate the solid particles from syngas. These particles are continuously returned to the riser's bottom. The recycle rate of the solids and the fluidization velocity are high enough to maintain the riser in a special fluidization condition. Typically, 
the syngas has heating values of about $5.0-6.0 \mathrm{MJ} / \mathrm{Nm}^{3}$ on dry basis using air as the oxidant. If oxygen is used as an oxidant, the syngas has heating values can reach $13.0-14.0 \mathrm{MJ} / \mathrm{Nm}^{3}$ on a dry basis [40].

Fixed bed and circulating fluidized bed gasifier technology has been applied in pulp and paper industry producing lime kiln fuel from biomass. Most practical experience exists from using circulating fluidized bed gasification [39]. In the eighties during the oil crises, circulating fluidized bed gasifiers were installed to produce fuel for lime kilns. The first commercial Foster Wheeler CFB gasifier (Former Ahlstrom Pyroflow CFB gasifiers) was supplied in 1983 to replace fuel oil in the lime kiln at Wisaforest mill in Finland, utilizing part of the generated gas for biomass drying [41]. Figure 6 shows an overview of the use of syngas in lime kilns.

Figure 6. Example of syngas as lime kiln fuel.

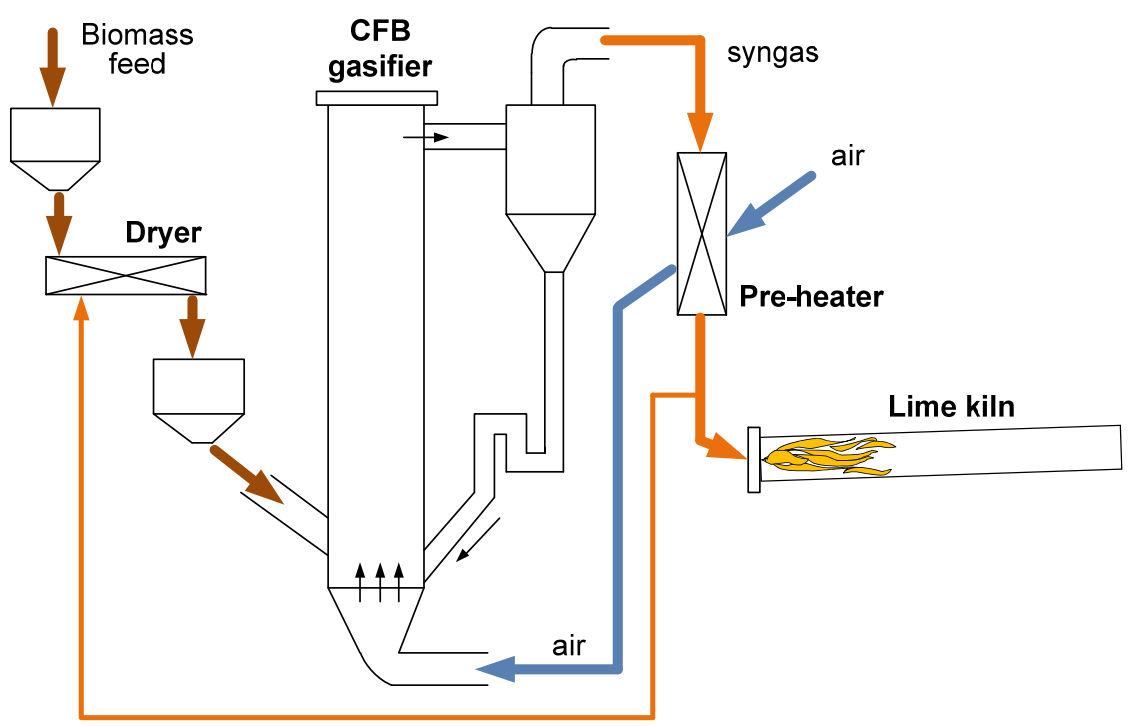

Since then, similar plants have been installed also in Sweden and Portugal. A biomass gasifier by Metso (former Götaverken) has been in function since 1987 in Södra Cell Värö pulp mill in Sweden [42]. In a more recent case, a Finnish pulp mill in Joutseno plans to replace $100 \%$ of the natural gas in the lime kiln by implementing a gasification unit supplied by Carbona/Andritz [43]. The wood residues are dried before gasification using waste heat available from mill. According to the project concept, the lime quality and burning efficiency will not be harmfully affected.

Two case studies involving biomass gasification integrated in the Billerud Karlsborg mill, Sweden, are analyzed by Wetterlund et al. [44]: BIGDME (Biomass Integrated Gasification Dimethyl Ether production) and BIGCC (Biomass Integrated Gasification Combined Cycle). They used some scenarios for 2030 , with different prices of fossil fuels and different levels of $\mathrm{CO}_{2}$ in the atmosphere. The annual cost of energy was then calculated for each concept and scenario. The results show that gasification of biomass for the production of electricity is more economically viable than the production of biofuels. It is important to point out that the conditions can differ from country to country due to differences in renewable energy policies or electricity market infrastructure. Currently there are, for example, large pulp mills being built in remote areas of Brazil. Selling substantial amount of electricity is sometimes not a good option since the connection to the local grid is limited. Guidelines could be then designed to stimulate the production and consumption of alternative biofuels. 


\subsubsection{Direct Liquefaction}

Applications of direct liquefaction of biomass are cited by Behrendt et al. [45]. One interesting example is the hydrothermal liquefaction (HTL), where water is an important reactant and catalyst, and thus the biomass can be directly converted without an energy consuming drying step [46]. In one application of this process, biomass is converted into an oily liquid by contacting water at elevated temperatures $\left(300-350^{\circ} \mathrm{C}\right)$ with high pressure (12-18 MPa) for a period between 5 and $20 \mathrm{~min}$. The product yield (mass percentage of dry input material), is about $45 \%$ bio-oil, $25 \%$ gas (mostly $\mathrm{CO}_{2}$ ), $20 \%$ water, and 10\% dissolved organic materials [45]. The bio-oil yield and quality however depend on the biomass specie and on many process conditions such as final liquefaction temperature, residence time, rate of biomass heating, size of particles and type of solvent media [47]. Cheng et al. [48] for example showed that white pine sawdust can be effectively liquefied using co-solvent of $50 \mathrm{wt} \%$ aqueous alcohol (methanol or ethanol) at $300{ }^{\circ} \mathrm{C}$ for $15 \mathrm{~min}$, which led to a bio-oil yield of $66 \mathrm{wt} \%$.

In general the high heating values in these HTL oils are in the range of 30 and $37 \mathrm{MJ} / \mathrm{kg}$ [46]. The oil however still contains high percentage of oxygen, making it more polar than crude oil. This causes some disadvantages such as relatively high water content, corrosive properties or thermal instability. The quality of the oil can be improved by subsequent hydro-treatment, which will increase productions costs. Although the HTL process is still under development, it has attracted increasing interest in processing biomass streams containing high water content.

\subsubsection{Bioethanol from Hemicellulose}

The production of ethanol from corn or sugarcane is relatively straightforward. They concentrate natural sugars that are easily fermented. However, production of ethanol from lignocellulosic biomass presents considerable challenges. Cellulose and hemicellulose have long-chain molecules made up of linked glucose sugar. They need a treatment step called hydrolysis to break up the larger chain of sugars into mono sugars. Yeasts and bacteria can then process these to produce ethanol. In pulp mills, hemicellulose can be extracted prior to pulping via hydrolysis and used for producing bioethanol, Figure 7.

Figure 7. Overview of hemicellulose recovery and bioethanol production.

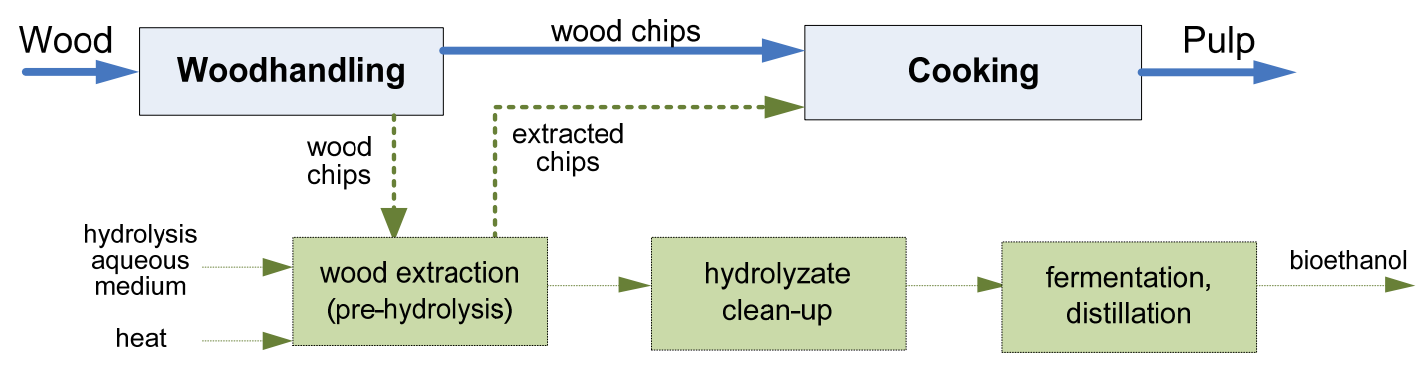

Different methods have been proposed for the aqueous phase extraction of hemicelluloses in combination with pulp production. In acidic pre-hydrolysis processes, hemicelluloses are hydrolyzed to oligomeric and monomeric sugars and dissolved in the hydrolyzate either in a dilute solution of a mineral acid, which acts as a catalyst of hydrolysis [49-51], or auto catalytically (auto-hydrolysis, $\mathrm{AH}$ or hydrothermal). In both processes, the hydrolysis is catalyzed by hydronium ions $\left(\mathrm{H}_{3} \mathrm{O}^{+}\right)$. In 
auto-hydrolysis, the acidic conditions are created through the cleavage of acetyl groups from xylan backbone and consequent release of acetic acid in hot water at a temperature of $130-175{ }^{\circ} \mathrm{C}$ [50-56]. In alkaline conditions, hemicellulose extraction has been carried out with green liquor in a so-called near-neutral process [57], with strong alkaline solutions at low temperatures [12], or with white liquor [58].

Table 6 shows experimental results from different pre-hydrolysis conditions with subsequent pulping of hydrolyzed chips. It can be observed that the auto-hydrolysis (AH) has been frequently tested. This process was already studied in the 50's [59], but with more emphasis on the pulp quality improvement. Currently, the process is being considered as an alternative for pulp mills that pursue a more thorough valorization of lignocellulosic components. The use of hot water can be favorable for many reasons: the PHL contains a reasonable amount of hemicellulose dissolved; the core fraction (cellulose) can be only slightly degraded; expenses with extra chemicals can be reduced; the use of water as aqueous phase is less harmful to the environment. In spite of these advantages, impacts on the mill operation are expected and have to be investigated. These include impacts on the equipment utilization capacity $[49,56]$ or the treatment of hydrolysis water to avoid the input of non-process elements such as potassium and chlorine.

Table 6. Impacts of different methods of pre-hydrolysis on the experimental cooking process.

\begin{tabular}{|c|c|c|c|c|c|}
\hline Wood & $\begin{array}{l}\text { Pre-hydrolysis } \\
\text { conditions time, T, } \\
\text { L:W, washing? }\end{array}$ & $\begin{array}{c}\text { Extraction } \\
\text { yield \% }\end{array}$ & $\begin{array}{l}\text { Pulping MaxT, sulfidity, } \\
\text { EA }^{4}, \text { L:W }\end{array}$ & $\begin{array}{c}\text { Overall } \\
\text { pulping yield } \\
\text { without (with) } \\
\text { extraction, \% }\end{array}$ & $\begin{array}{c}\text { Extracted matter } \\
\text { analysis wt \% or g/L }\end{array}$ \\
\hline \multirow{2}{*}{ E. globules [51] } & $\begin{array}{c}\text { AH (hot water) } 3 \mathrm{~h}, \\
150^{\circ} \mathrm{C}, 4: 1, \text { yes }\end{array}$ & 12.5 & $160^{\circ} \mathrm{C}, 28 \%, 17.4 \%, 4: 1$ & $54.7(45.1)$ & $\begin{array}{l}1-4 \mathrm{~g} / \mathrm{L} \text {, as } \\
\text { ethanol conc. }\end{array}$ \\
\hline & $\begin{array}{c}\text { Acid }\left(0.4 \mathrm{H}_{2} \mathrm{SO}_{4}\right)^{2} 2 \mathrm{~h}, \\
140{ }^{\circ} \mathrm{C}, 4: 1, \text { yes }\end{array}$ & 13.1 & $160{ }^{\circ} \mathrm{C}, 28 \%, 17.4 \%, 4: 1$ & $54.7(39.7)$ & $\begin{array}{l}6.8-9.6 \mathrm{~g} / \mathrm{L} \text {, as } \\
\text { ethanol conc. }\end{array}$ \\
\hline $\begin{array}{l}\text { E. urograndis } \\
{[52]} \\
\end{array}$ & $\begin{array}{c}\text { AH (hot water) } 0.5 \mathrm{~h}, \\
165^{\circ} \mathrm{C}, 3.5: 1, \text { no }\end{array}$ & 10.8 & $\begin{array}{c}155^{\circ} \mathrm{C}, 37 \%, 15.8 \%, \\
3.5: 1\end{array}$ & $53.9(41.9)$ & $\begin{array}{l}\sim 40 \% \text { of dry } \\
\text { PHL as xylan }\end{array}$ \\
\hline \multirow{2}{*}{ Birch [58] } & $\begin{array}{l}\text { AH (hot water) } 1.5 \mathrm{~h}, \\
150^{\circ} \mathrm{C}, 3: 1, \text { no }\end{array}$ & 8.0 & $160{ }^{\circ} \mathrm{C}, 36 \%, 21 \%, 3.5: 1$ & $51.7(43.2)$ & $11.75 \mathrm{~g} / \mathrm{L}$ as xylan \\
\hline & $\begin{array}{l}\text { Alkali (white liquor) } \\
31 \mathrm{~h}, 160^{\circ} \mathrm{C}, 3: 1 \text {, no }\end{array}$ & 9.0 & $160{ }^{\circ} \mathrm{C}, 36 \%, 18 \%, 3.5: 1$ & $51.7(46.0)$ & $3.62 \mathrm{~g} / \mathrm{L}$ as xylan \\
\hline $\begin{array}{c}\text { North. hardw } \\
\text { [57] }\end{array}$ & $\begin{array}{l}\text { Alkali (green liquor) } \\
1.8 \mathrm{~h}, 160^{\circ} \mathrm{C}, 4: 1 \text {, no }\end{array}$ & 9.0 & $160{ }^{\circ} \mathrm{C}, 30 \%, 14 \%, 4: 1$ & $48.0(46.0)$ & $\begin{array}{c}40 \% \text {, as fermentable } \\
\text { sugars }\end{array}$ \\
\hline \multirow{2}{*}{ Aspen $[12,50]$} & $\begin{array}{c}\text { AH (hot water) } 4.5 \mathrm{~h}, \\
150{ }^{\circ} \mathrm{C}, 4: 1, \text { no }\end{array}$ & 19.0 & $160{ }^{\circ} \mathrm{C}, 25 \%, 21 \%, 4: 1$ & $53.3(39.7)$ & $46 \%$ as xylan \\
\hline & $\begin{array}{c}\text { Alkali }(1.67 \mathrm{M} \mathrm{NaOH}) \\
4 \text { h, } 90^{\circ} \mathrm{C}, 4: 1, \text { no }\end{array}$ & 19.3 & $170{ }^{\circ} \mathrm{C}, 39.8 \%, 12 \%, 4: 1$ & $52.7(53.3)$ & $27.3 \%$ as xylan \\
\hline \multirow{2}{*}{ Pine $[49,56]$} & $\begin{array}{c}\text { Acid }\left(0.5 \mathrm{H}_{2} \mathrm{SO}_{4}\right)^{2} 1 \mathrm{~h}, \\
150{ }^{\circ} \mathrm{C}, 5: 1 \text {, yes }\end{array}$ & 14.0 & $165^{\circ} \mathrm{C}, 30 \%, 16 \%, 4: 1$ & $46.6(36.5)$ & $\begin{array}{c}\sim 70 \% \text { carbohydrates } \\
\quad(\sim 50 \% \text { hemicel. })\end{array}$ \\
\hline & $\begin{array}{l}\text { AH (hot water) } 1.7 \mathrm{~h}, \\
150^{\circ} \mathrm{C}, 4: 1, \text { no }\end{array}$ & 14.1 & $160^{\circ} \mathrm{C}, 40 \%, 19.4 \%, 4: 1$ & $46.2(40.0)$ & $48 \%$ carbohydrates \\
\hline
\end{tabular}

\footnotetext{
${ }^{1}$ washing post hydrolysis, which may affect the cooking process due to PHL entrained in the pores; ${ }^{2}$ wt $\%$ on dry wood;

${ }^{3}$ EA $3 \% ;{ }^{4}$ as $\mathrm{NaOH}$.
} 
The auto-hydrolysis process has some drawbacks, which include high investment and energy costs of the water pre-hydrolysis step as well as the expensive waste disposal of the PHL caused by the formation of sticky precipitates [60]. The formation of these precipitates is attributed to condensation products created by fragments of lignin dissolved in the PHL. Their content is determined by the auto-hydrolysis duration. This change in the lignin reactivity during hydrolysis can make the processing of PHL very difficult, affecting also the efficiency of subsequent cooking operations [61]. Since the content of degradation products are determined by the auto-hydrolysis duration, the time becomes an important aspect for the feasibility study. Although the auto-hydrolysis can reduce the impacts on pulp quality, it requires a post-hydrolysis step to increase the concentration of fermentable sugars for ethanol production [51].

The temperature has also a great influence on the hydrolysis process. As an example, for the same extraction yield, the auto-hydrolysis time can be significantly reduced by increasing the water temperature. Drawing from Table 1, however, one can conclude that a preferable condition for hemicellulose extraction is still not clear. Although it shows that the overall pulping yield is less affected with alkaline pre-hydrolysis, the amount of recovered xylan can be significantly lower when compared to dilute acid or auto hydrolysis. In the case of dilute acid, the cellulose can be highly degraded depending on the hydrolysis conditions [49], which can lead to a poorer quality of pulp. It is important to bear in mind that since hemicelluloses are extracted prior to pulping, both the fiber line and chemical recovery can be affected. The specific effects therefore will strongly depend on the extraction process and the amount of wood extracted. The impact on the pulp yield will directly affect the specific consumption of wood and the black liquor yield.

\subsection{Black Liquor-Based Technologies}

The technologies presented in this section involve processing the black liquor to produce biofuels. They are divided into three processes: Lignin removal, gasification and processing of tall oil to produce biodiesel, Figure 8 .

Figure 8. Technologies for biofuel production using black liquor as a source.

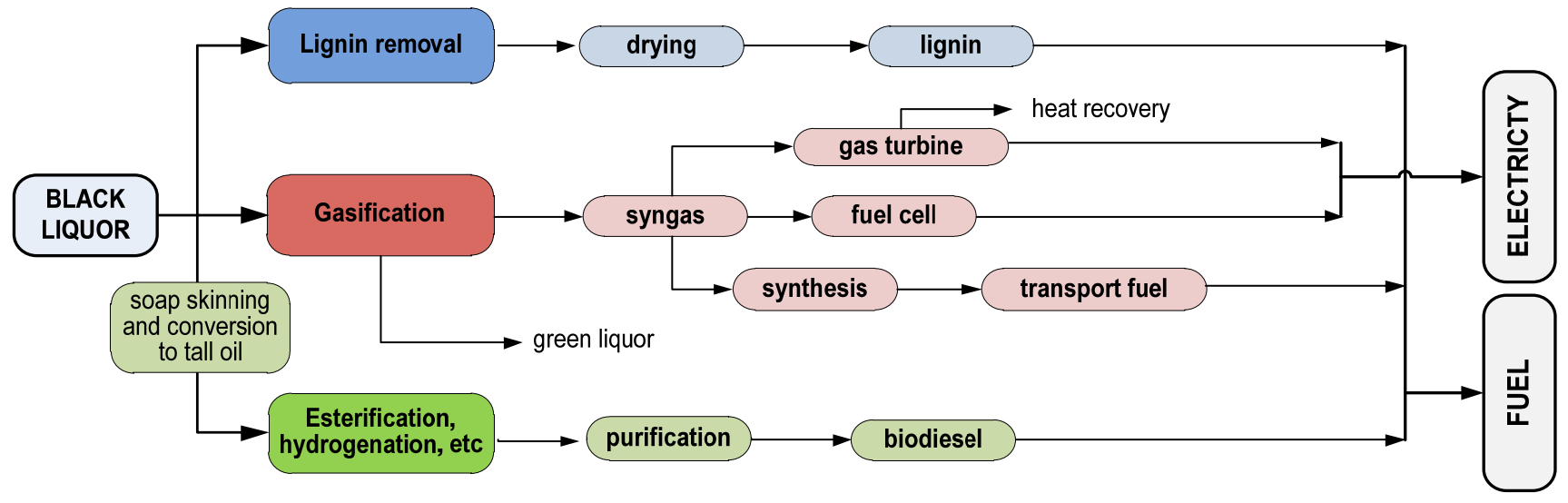




\subsubsection{Lignin Removal}

The idea of separating lignin from black liquor has been advocated since mid-1940s, when Tomlinson and Tomlinson [62] applied the liquor carbonation method using $\mathrm{CO}_{2}$-containing gases. Since then, important contributions have been made towards improving the process [63-65]. The technology can be used not only to debottleneck overloaded recovery boilers but also to produce a solid biofuel with high energy density and low ash content. The most common separation process is the lignin precipitation from black liquor by acidification, which can be done by using mineral acid and $\mathrm{CO}_{2}$. The method was improved jointly by STFI and Chalmers University of Technology [66], Figure 9.The black liquor from the evaporator is led into the acidification phase at a dry solids content of $30 \%-45 \%$. In this phase, $\mathrm{CO}_{2}$ is mixed into the liquor to reduce the $\mathrm{pH}$, which results in the precipitation of lignin. The lignin is then dewatered using a press filter dissolved again with wash water. The $\mathrm{pH}$ is decreased during conditioning with sulfuric acid. The slurred lignin is filtered again and the filtrate is introduced back to the evaporation plant.

Figure 9. Overview of Lignoboost process.

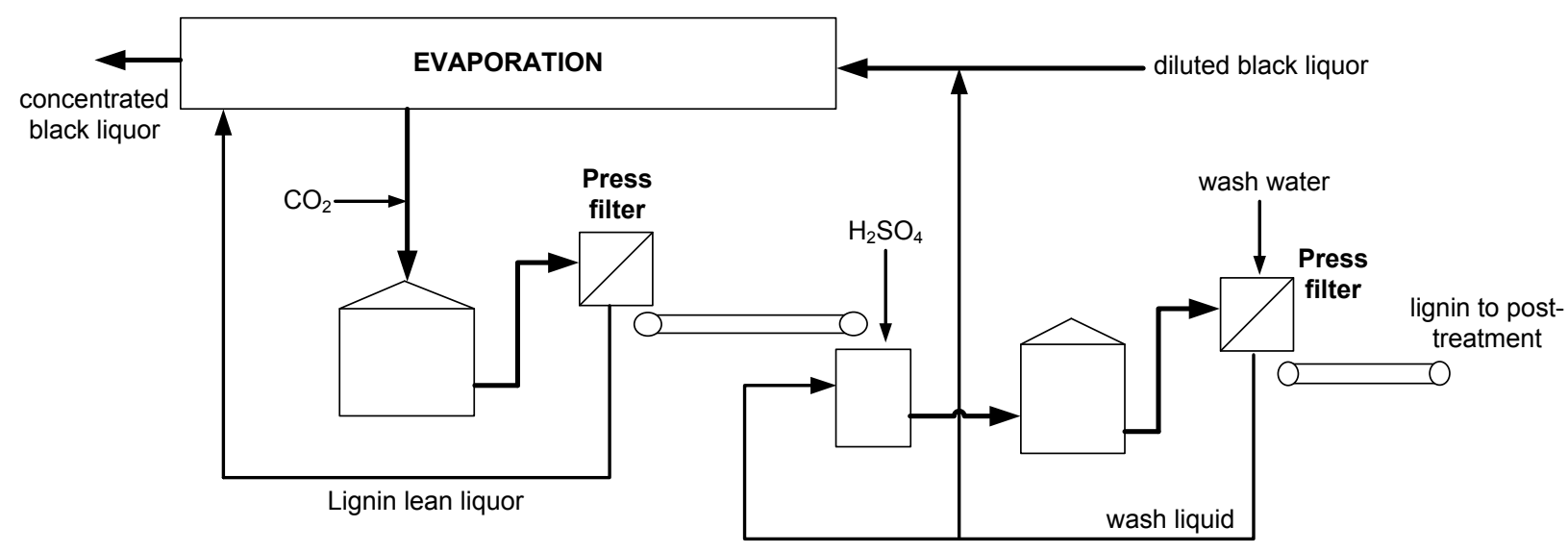

The separated lignin can be used for producing biomaterials or chemicals. An immediate option is the combustion for heat and power generation. The burning of separated lignin in lime kilns was studied in the late 1980s [67] and is considered a viable option. It is important to point out however that the removal rates are limited by the impacts they cause on the mill operation. When lignin is removed, it will affect mostly the chemical recovery process and steam generation rate [39]. The reason is that about $60 \%$ of the black liquor heating value comes from the lignin. These impacts should be taken into consideration when being compared with the production of biofuels from the wood residues. Some variables are demonstrated in Table 7 for one eucalyptus pulp mill [16].

Table 7. Calculated values for different lignin removal rates in one eucalyptus pulp mill.

\begin{tabular}{ccccc}
\hline Variable & \multicolumn{3}{c}{ Percentage of Lignin Removal } \\
\cline { 2 - 5 } & $\mathbf{0 \%}$ & $\mathbf{1 0 \%}$ & $\mathbf{2 0 \%}$ & $\mathbf{3 0 \%}$ \\
\hline Recovery boiler steam production, $\mathrm{t} / \mathrm{h}$ & 890 & 825 & 760 & 696 \\
Heat load into recovery boiler, MW & 948 & 889 & 831 & 772 \\
Lignin/total dry solids in black liquor, wt \% & 36.3 & 33.9 & 31.3 & 28.5 \\
Power generation, MW & 192.9 & 174.9 & 156.4 & 137.5 \\
\hline
\end{tabular}




\subsubsection{Black Liquor Gasification (BLG)}

The BLG is a specific application for kraft pulp mills. The residual liquor is gasified in a reactor under reducing conditions. There are two gasification processes that have been tried [68]: low temperature in the range from $600{ }^{\circ} \mathrm{C}$ to $850{ }^{\circ} \mathrm{C}$, where the inorganic compounds are below their melting point, and high temperature 800 to $1200{ }^{\circ} \mathrm{C}$ which produces molten smelt. The generated gas is always separated from inorganic compounds (i.e., ash). To recover heat the syngas and inorganic compounds are cooled and inorganics are dissolved in water (or weak white liquor) to form green liquor in an identical manner as in the dissolving tank of the traditional kraft pulp mill.

Different technologies for BLG are available, which include: Manufacturing and Technology Conversion International (MTCI) process, Direct Alkali Regeneration System (DARS) process, and the Chemrec process, each with its own distinctiveness. Others under development are the Supercritical Water Oxidation (SCWO) and BLG with direct causticization, which can be integrated without the need of the recausticizing unit. Figure 10 shows an example of Chemrec process [43]. The core units are the entrained flow reactor with the quench cooler, the counter current gas cooler, and heat exchangers for cooling the hot green liquor. Black liquor and oxygen is fed in the top of the reactor. The residence time in the reactor is about 5 seconds, with the temperature normally kept steadily slightly above $1000{ }^{\circ} \mathrm{C}$. The $\mathrm{H}_{2} \mathrm{~S}$ in the cooled raw gas $\left(1.4\right.$ vol \%-2.5 vol \%) is removed in the $\mathrm{H}_{2} \mathrm{~S}$ absorption unit.

Figure 10. Simplified diagram of Chemrec BLG.

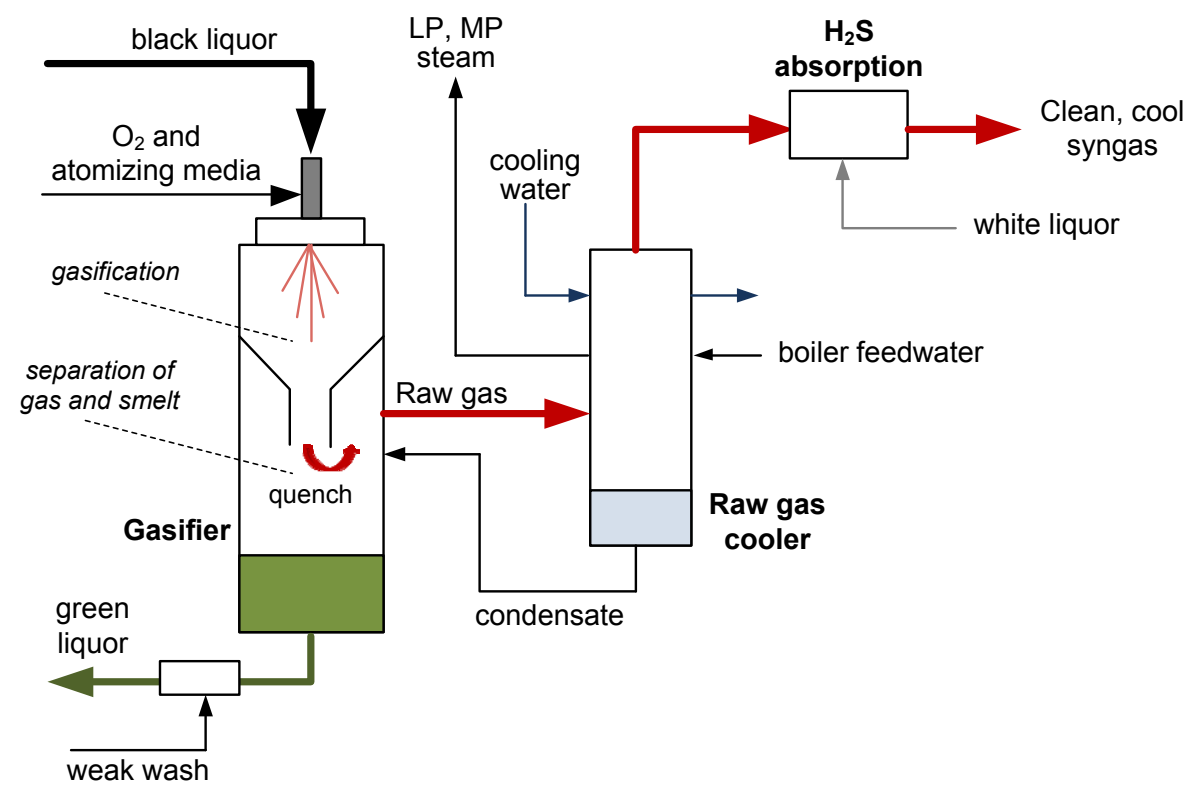

Naqvi et al. [68] highlight the potential of the black liquor to generate fuel and energy and present a series of studies being developed in the area of BLG integrated in pulp and paper mills. One disadvantage of the recovery boiler is the great precautions that have to be taken to avoid explosions between water and smelt. This can be corrected with the implementation of the gasification system. Although recovery boiler processes can achieve as good efficiencies as gasification processes [69], the BLG allows the production of alternative fuels such as DME or methane [70]. In spite of these 
benefits, there are still challenges in implementing the BLG. One is determining the appropriate choice of the best material for the refractory lining in the gasification reactor. There is a consensus that what we have today is not appropriate, in that the environment in the gasifier is very aggressive with high temperatures and alkalinity.

Another challenge is that in the conventional process, all of the sulfur is recovered in the process, however, in the BLG integrated in pulp and paper mills, only a portion of the sulfur is converted to $\mathrm{Na}_{2} \mathrm{~S}$ and the majority of the synthetic gas exits as $\mathrm{H}_{2} \mathrm{~S}$ and $\mathrm{COS}$. This leaves excess sodium which leads to additional $\mathrm{Na}_{2} \mathrm{CO}_{3}$ to recausticizing. Therefore, alternatives are needed to recovery the sulfur in the form of $\mathrm{H}_{2} \mathrm{~S}$ or to avoid excessive overloading recausticizing in lime kiln. The direct causticizing is one option to be considered, although more research on the pulping step should be performed. Nohlgreen and Sinquefield [71] present the main reactions in the gasifier using titanium dioxide. In one of these steps, when the sodium oxide titane is leached in water, $\mathrm{NaOH}$ is directly formed.

\subsubsection{Biodiesel from Tall-Oil}

Crude tall oil (CTO) is the acidified product of soap and an important by-product in the kraft pulping of coniferous wood such as pine ("tall" in Swedish). These species have a reasonable amount of extractives. As a consequence, in alkaline conditions, sodium salts of fatty and resin acids are formed by saponification and become partly soluble in the black liquor [72]. The soap can be separated from black liquor due to density differences and the optimum dry solids content for the soap skimming is between $28 \%$ and $32 \%$. The acidulation process is subsequently required to convert the soap into CTO. The yield per ton of pulp depends on the wood species, part of wood trunk, season, soil quality or storage period. For Scots pine, for example, it falls in a range of $20-100 \mathrm{~kg} / \mathrm{CTO} / \mathrm{Adt}$. Typically, the CTO is depitched and then upgraded to produce more valuable products such as tall oil fatty acids and oil rosin [73]. Again, it is important to emphasize the relevance of wood species, since the content of fatty acids, Table 8 , plays an important role in the production of biodiesel.

Table 8. Examples of distribution of tall oil extractives, wt \% [74].

\begin{tabular}{ccccc}
\hline Component & $\begin{array}{c}\text { N. American } \\
\text { softwood }\end{array}$ & $\begin{array}{c}\text { N. American } \\
\text { hardwood }\end{array}$ & $\begin{array}{c}\text { Scandinavian } \\
\text { pine }\end{array}$ & $\begin{array}{c}\text { Scandinavian } \\
\text { spruce }\end{array}$ \\
\hline Rosin acids & 42 & - & $30-35$ & $20-30$ \\
Fatty acids & 47 & 76 & $50-55$ & $35-55$ \\
Neutrals & 11 & 24 & $5-10$ & $18-25$ \\
\hline
\end{tabular}

Separation of soap from black liquor is important to avoid disturbances in the evaporators and in the fibre quality. The resulting tall oil can be used as auxiliary fuel or sold to outside companies to produce for example detergents, lubricants or varnishes. Production of biodiesel [75,76] is also an interesting tentative of adding more value to the CTO. The UPM group will start producing annually, in southeastern Finland, approximately 100,000 tons of biodiesel for transport using crude tall oil [77]. The industrial scale investment is the first of its kind globally.

In typical industrial applications, the vegetal triglyceride oils are converted to their lower viscosity methyl esters via acid or base transesterifcation to produce biodiesel. With tall oil, some strategic processes include acid-catalyzed esterification, enzymatic processes, hydrogenation and the use of 
supercritical methanol [73]. The latter two seem to be a good choice. White et al. [78] investigated the reaction of methanol with tall oil at high temperature and supercritical pressures to produce fatty acid methyl esters (FAME). The process seems promising especially because the reaction proceeds without the need for additional catalysts. In addition, it has advantages when compared to catalytic or enzymatic processes in terms of reaction time and yield. The biodiesel produced by hydrogenation has a high cetane number $(\mathrm{CN})$ close to 60 . The process is demonstrated by Canada [73] and involves simultaneous catalytic hydrogenation and cracking of the depitched tall oil. Because the $\mathrm{CN}$ is related to the ignition delay time of a fuel upon injection into the combustion chamber, the resulting biodiesel can be used as cetane enhancer in petrodiesel blends.

\section{Conclusions}

This review shows that there is a potential for kraft pulp mills to produce alternative biofuels in addition to the traditional market pulp, with some technologies such as gasification, lignin removal or biodiesel from tall oil already operating or being implemented. The attractiveness of these processes depends on many factors such as wood species processed, energy policies, economic (prices of pulp, wood, biofuels or electricity), scale of production, process maturity, end-use requirements and effects that the integration would cause on existing mills. The case of ethanol from hemicellulose can be more critical due to the possible impacts on the pulp quality. In this sense, the use of wood residues and tall oil is more favorable. Regarding biodiesel, especially mills processing softwood have the potential to use the tall oil. Some options are still being improved to become more competitive. Examples include Fischer-Tropsch process, catalytic synthesis to produce hydrogen, upgrading of bio-oil or black liquor gasification. Others technologies, such as pelletizing, are well established but would have less value added when compared to liquid transportation fuels from biomass.

\section{References}

1. FitzPatrick, M.; Champagne, P.; Cunningham, M.F.; Whitney, R.A. A biorefinery processing perspective: Treatment of lignocellulosic materials for the production of value-added products. Bioresour. Technol. 2010, 101, 8915-8927.

2. Smook, G. Handbook for Pulp \& Paper Technologists, 3rd ed.; Angus Wilde Publications, Inc.: Vancouver, Canada, 2002.

3. Marinova, M.; Espejel, E.M.; Jemaa, N.; Paris, J. Addressing the increased energy demand of a Kraft mill biorefinery: The hemicellulose extraction case. Chem. Eng. Res. Des. 2009, 87, 1269-1275.

4. Doherty, W.O.S.; Mousavioun, P.; Fellows, C.M. Value-Adding to cellulosic ethanol: Lignin polymers. Ind. Crop. Prod. 2011, 33, 259-276.

5. Van der Weerdhof, M.W. Modeling the Pyrolysis Process of Biomass Particles. Master's Thesis, Eindhoven University of Technology, Eindhoven, The Netherlands, 2010.

6. Sheng, C.; Azevedo, J.L.T. Estimating the higher heating value of biomass from basic analysis data. Biomass Bioenergy 2005, 28, 499-507.

7. Telmo, C.; Lousada, J. The explained variation by lignin and extrative contents on higher heating value of wood. Biomass Bioenergy 2011, 5, 1663-1667. 
8. Saidur, R.; Abdelaziz, E.A.; Bemirbas, A.; Hossain, M.S.; Mekhilef, S.A. A review on biomass as a fuel for boilers. Renew. Sust. Energy Rev. 2011, 15, 2262-2289.

9. Gullichsen, J. Fiber Line Operations. In Book Chemical Pulping 6A; Gullichsen, J., Fogelhom, C.-J., Eds.; Fapet Oy: Jyväskylä, Finland, 2000; pp. 18-243.

10. Sjöström, E. Wood Chemistry-Fundamentals and Applications; Academic Press: Orlando, FL, USA, 1981.

11. Mokfienski, A.; Colodette, J.L.; Gomide, J.L.; Carvalho, A.M. A importância relativa da densidade da madeira e do teor de carboidratos no rendimento de polpa e na qualidade do produto. Ciência Florestal 2008, 18, 401-413.

12. Al-Dajani, W.W.; Tschirner, U.W. Pre-extraction hemicelluloses and subsequent kraft pulping Part I: Alkaline extraction. Tappi J. 2008, 7, 3-8.

13. Shackford, D.L. A Comparison of Pulping and Bleaching of Kraft Softwood and Eucalyptus Pulps. In Proceedings of the 36th International Pulp and Paper Congress, São Paulo, Brazil, 13-16 October 2003.

14. Santos, R.B.; Capanema, E.A.; Balakshin, M.Y.; Chang, H.-M.; Jameel, H. Effect of hardwood lignin structure on the kraft pulping process: Emphasis on lignin structure. Bioresources 2011, 6, 3623-3637.

15. Grace, T.M.; Malcolm, E.W. Chemical Reactions of Wood Constituints. In Book Pulp and Paper Manufacture Volume 5; Alkaline Pulping, TAPPI\&CPPA: Atlanta, GA, USA, 1989; pp. 23-44.

16. Hamaguchi, M.; Vakkilainen, E.; Ryder, P. The impact of lignin removal on the dimensioning of eucalyptus pulp mills. Appita J. 2011, 64, 433-438.

17. Elliott, A.; Mahmood, T. Pretreatment technologies for advancing anaerobic digestion of pulp and paper biotreatment residues. Water Res. 2007, 41, 4273-4286.

18. Lehtikangas, P. Quality properties of pelletised sawdust, logging residues and bark, logging residues and bark. Biomass Bioenergy 2001, 20, 351-360.

19. Johansson, I.; Larsson, S.; Wennberg, O. Torkning av Biobränslen Med Spillvärme; Report number 881; Värmeforsk Service AB: Värmeforsk, Sweden, 2004.

20. Kaliyan, N.; Morey, R.V. Factors affecting streng and durability of densified biomass products. Biomass Bioenergy 2009, 33, 337-359.

21. Anderson, E.; Harvey, S.; Berntsson, T. Energy efficient upgrading of biofuel integrated with a pulp mill. Energy 2006, 31, 1384-1394.

22. Schwob, Y. Process for converting ligneous matter from vegetable origin by torrefaction, and product obtained thereby. US Patent 4553978, 19 November 1985.

23. Medic, D.; Darr, M.; Shah, A.; Rahn, S. The effects of particle size, different corn stover components, and gas residence time on torrefaction of corn stover. Energies 2012, 5, 1199-1214.

24. Van der Stelt, M.J.C.; Gerhauser, H.; Kiel, J.H.A.; Ptasinski, K.J. Biomass upgrading by torrefaction for the production of biofuels: A review. Biomass Bioenergy 2011, 35, 3748-3762.

25. Prins, M.J.; Ptasinski, K.J.; Janssen, F.J.J.G. More efficient biomass gasification via torrefaction. Energy 2006, 31, 3458-3470.

26. Kumar, A.; Jones, D.D.; Hanna, M.A. Thermochemical biomass gasification: A review of the current status of the technology. Energies 2009, 2, 556-581.

27. Kleinschmidt, C. Overview of International Developments in Torrefaction. In Proceedings of the IEA Bioenergy Task 40: Sustainable Bioenergy Trade Workshop, Graz, Austria, 28 January 2011. 
28. Basu, P. Biomass Gasification and Pyrolysis Practical Design and Theory; Elsevier Inc.: Oxford, UK, 2010; pp. 65-228.

29. Demirbas, A. Biorefineries: Current activities and future developments. Energy Convers. Manag. 2009, 50, 2782-2801.

30. Czernik, S.; Bridgwater, A.V. Overview of applications of biomass fast pyrolysis oil. Energy Fuels 2004, 18, 590-598.

31. METSO. Novel solutions for pulp mill energy intensification. Results pulp and paper 3/2010. Available online: http://www.metso.com (accessed on 16 May 2012).

32. Liukko, K. Rapid Thermal Processing (RTP) - A Proven Pathway to Second Generation Biofuels. In Proceedings of the XXI TEcnicelpa Conference and Exhibition/VI Ciadicyp, Lisbon, Portugal, 12-15 October 2010.

33. Envergent Technologies, RTP Yields. Available online: http://www.envergenttech.com/rtp.php (accessed on 15 May 2012).

34. Diebold, J.P. A Review of the Chemical and Physical Mechanisms of the Storage Stability of Fast Pyrolysis Bio-Oils; Subcontractor Report NREL/SR-570-2761; NREL: Lakewood, CO, USA, 2000.

35. Bridgwater, A.V. Review of fast pyrolysis of biomass and product upgrading. Biomass Bioenergy 2012, 38, 68-94.

36. Chiaramonti, D.; Oasmaa, A.; Solantausta, Y. Power generation using fast pyrolysis liquids from biomass. Renew. Sust. Energy Rev. 2007, 11, 1056-1086.

37. Saxena, R.C.; Seal, D.; Kumar, S.; Goyal, H.B. Thermo-Chemical routes for hydrogen rich gas from biomass: A review. Renew. Sust. Energy Rev. 2008, 12, 1909-1927.

38. Semelsberger, T.A.; Borup, R.L.; Greene, H.L. Dimethyl ether (DME) as an alternative fuel. J. Power Sources 2006, 156, 497-511.

39. Vakkilainen, E.; Kivistö, A. Fossil Fuel Replacement in the Pulp Mills; Research Report EN A-58; Lappeenranta University of Technology: Lappeenranta, Finland, 2008.

40. Bain, R.L.; Broer, K. Thermochemical Processing of Biomass: Conversion into Fuels, Chemicals and Power; Brown, R.C., Ed.; John Wiley \& Sons Inc.: Chichester, UK, 2011; p. 54.

41. Palonen, J.; Nieminen, J. Biomass CFB Gasifier Connected to a 350 MWth Steam Boiler Fired with Coal and Natural Gas-THERMIE Demonstration Project at Kymijärvi CHP Power Station in Lahti, Finland. In Proceedings of the Power-Gen Europe, Frankfurt, Germany, 1-3 June 1999.

42. Isaksson, J. Biomass Gasification for Lime Kiln Applications. In Proceedings of the 7th Colloquium on Black Liquor Combustion and Gasification, Jyväkylä, Finland, 31 July 2006.

43. Hrbek, J. Biomass Gasification Opportunities in Forest Industry. In Proceedings of IEA Bioenergy Task 33 Workshop, Piteå, Sweden, 19 October 2011.

44. Wetterlund, E.; Pettersson, K.; Havery, S. Systems analysis of integrating biomass gasification with pulp and paper production-effects on economic performance, $\mathrm{CO}_{2}$ emissions and energy use. Energy 2011, 36, 932-941.

45. Behrendt, F.; Neubauer, Y.; Oevermann, M.; Wilmes, B.; Zobel, N. Direct liquefaction of biomass. Chem. Eng. Technol. 2008, 31, 667-677.

46. Toor, S.S.; Rosendahl, L.; Rudolf, A. Hydrothermal liquefaction of biomass: A review of subcritical water technologies. Energy 2011, 36, 2328-2342. 
47. Akhtar, J.; Amin, N.A.S. A review on process conditions for optimum bio-oil yield in hydrothermal liquefaction of biomass. Renew. Sust. Energy Rev. 2011, 15, 1615-1624.

48. Cheng, S.; D'cruz, I.; Wang, M.; Leitch, M.; Xu, C. Highly efficient liquefaction of woody biomass in hot-compressed alcohol-water co-solvents. Energy Fuels 2010, 24, 4659-4667.

49. Frederick, W.J.; Lien, S.J.; Courchene, C.E.; DeMartini, N.A.; Ragauskas, A.J. Co-production of ethanol and cellulose fiber from Southern Pine: A technical and economic assessment. Biomass Bioenergy 2008, 32, 1293-1302.

50. Al-Dajani, W.W.; Tschirner, U.W.; Jensen, T. Pre-extraction hemicelluloses and subsequent kraft pulping Part II: Acid- and autohydrolysis. Tappi J. 2009, 8, 30-37.

51. Mendes, C.V.T.; Carvalho, M.G.V.S.; Baptista, C.M.S.G.; Rocha, J.M.S.; Soares, B.I.G.; Sousa, G.D.A. Valorisation of hardwood hemicelluloses in the kraft pulping process by using an integrated biorefinery concept. Food Bioprod. Proc. 2009, 87, 197-207.

52. Colodette, J.L.; Longue, D.; Pedrazzi, C.; Oliveira, C.R.; Gomide, J.L.; Gomes, F.J.B. Pulpability and bleachability of xylan-depleted eucalyptus wood chips. Ind. Eng. Chem. Res. 2011, 50, 1847-1852.

53. Casebier, L.C.; Hamilton, J.K. Chemistry and mechanism of water prehydrolysis on southern pine wood. Tappi J. 1969, 52, 2369-2377.

54. Garrote, G.; Parajó, J.C. Nonisothermal autohydrolysis of Eucalyptus wood. Wood Sci. Technol. 2002, 36, 111-123.

55. Yoon, S.H.; MacEwan, K.; van Heiningen, A. Hot-water pretreatment from loblolly pine (Pinus taeda) in an integrated forest products biorefinery. Tappi J. 2008, 7, $27-31$.

56. Kautto, J.; Henricson, K.; Sixta, H.; Trogen, M.; Alén, R. Effects of integrating a bioethanol production process to a kraft pulp mill. Nord. Pulp Pap. Res. J. 2010, 25, 233-242.

57. Mao, H.; Genco, J.M.; van Heiningen, A.; Pendse, H. Kraft mill biorefinery to produce acetic acid and ethanol: Technical economic analysis. BioResources 2010, 5, 525-544.

58. Helmerius, J.; von Walter, J.V.; Rova, U.; Berglund, K.A.; Hodge, D.B. Impact of hemicellulose pre-extraction for bioconversion on birch Kraft pulp properties. Bioresour. Technol. 2010, 101, 5996-6005.

59. Richter, G.A. Some aspects of prehydrolysis pulping. Tappi J. 1956, 39, 193-210.

60. Sixta, H.; Schield, G. A new generation kraft process. Lenzing. Ber 2009, 87, 26-37.

61. Leschinsky, M.; Zuckerstätter, G.; Weber, H.K.; Patt, R.; Sixta, H. Effects of autohydrolysis of Eucalyptus globulus wood on lignin structure. Part 1: Comparison of different lignin fractions formed during water prehydrolysis. Holzforschung 2008, 62, 653-658.

62. Tomlinson, G.H.; Tomlinson,G.H., Jr. Improvements in the recovery of lignin from black liquor. US Patent $664811,1952$.

63. Uloth, V.C.; Wearing, T.J. Kraft lignin recovery: Acid precipitation versus ultrafiltration. Part I: Laboratory test results. Pulp Pap. Can. 1989, 90, 310-314.

64. Merewether, J.W.T. Lignin. XIV. The precipitation of lignin from kraft black liquor. Holzforschung 1961, 15, 168-177.

65. Alen, R.; Patja, P.; Sjostrom, E. Carbon dioxide precipitation of lignin from pine kraft black liquor. Tappi J. 1979, 62, 108-110.

66. Tomani, P. The LignoBoost process. Cellul. Chem. Technol. 2010, 44, 53-58. 
67. Richardson, B.; Watkinson, A.P.; Barr, P.V. Combustion of lignin in a pilot lime kiln. Tappi J. 1990, 73, 133-145.

68. Naqvi, M.; Yan, J.; Dahlquist, E. Black liquor gasification integrated in pulp and paper mills: A critical review. Bioresour. Technol. 2010, 101, 8001-8015.

69. Vakkilainen, E.; Suutela, J.; Kankkonen, S. Advanced efficiency options-increasing electricity generating potential from pulp mills. Pulp Pap. Can. 2008, 109, 14-19.

70. Naqvi, M.; Yan, J.; Fröling, M. Bio-refinery system of DME or CH4 production from black liquor gasification in pulp mills. Bioresour. Technol. 2010, 101, 937-944.

71. Nohlgren, I.M.; Sinquefield, S.A. Black liquor gasification with direct causticizing using titanates: Equilibrium calculations. Ind. Eng. Chem. Res. 2004, 43, 5996-6000.

72. Laxén T.; Tikka, P. Soap and Tall Oil. In Book Chemical Pulping Part 2, book 6; Tikka, P., Ed.; Fapet Oy: Jyväskylä, Finland, 2008; pp. 360-379.

73. Prakash, C.B. A Critical Review of Biodiesel as a Transportation Fuel in Canada; Technical Report; Global Change Strategies International: Ottawa, Canada, 1998.

74. Holmlund, K.; Parviainen, K. Evaporation of Black Liquor, In Book Chemical Pulping 6A; Gullichsen, J., Fogelhom, C.-J., Eds.; Fapet Oy: Jyväskylä, Finland, 2000; p. 83.

75. Lee, S.Y.; Hubbe, M.A.; Saka, S. Prospects for biodiesel as a byproduct of woof pulping-A review. Bioresources 2006, 1, 150-171.

76. Demirbas, A. Production of biodiesel from tall oil. Energy Sour. Part A 2008, 30, 1896-1902.

77. UPM Biofuels. Available online: http://www.upm.com (accessed on 13 May 2012).

78. White, K.; Lorenz, N.; Potts, T.; Roy Penney, W.; Babcock, R.; Hardison, A.; Canuel, E.A.; Hestekin, J.A. Production of biodiesel fuel from tall oil fatty acids via high temperature methanol reaction. Fuel 2011, 90, 3193-3199.

(C) 2012 by the authors; licensee MDPI, Basel, Switzerland. This article is an open access article distributed under the terms and conditions of the Creative Commons Attribution license (http://creativecommons.org/licenses/by/3.0/). 